\title{
AC 2008-1907: THE IMPACT OF OUT-OF-SCHOOL TIME (OST) MATH AND SCIENCE CLUBS ON ELEMENTARY AND MIDDLE SCHOOL STUDENTS, TEACHERS, SCHOOLS AND THE UNDERGRADUATE AND GRADUATE FELLOWS THAT FACILITATE THEM
}

\section{Lynn Albers, North Carolina State University}

Lynn Albers is a third-year NSF-GE Foundation RAMP-UP graduate Fellow. She received her B.S. in Mathematics with a minor in Music from MIT in 1992 and her M.S. in Mechanical Engineering with a minor in Nuclear Engineering from Manhattan College in 1996. After working for Nortel Networks and the NC Solar Center, Lynn matriculated at North Carolina State University where she is a Ph.D. candidate in Mechanical Engineering, focusing on renewable energy.

\section{Althea Smith, North Carolina State University}

Althea Smith is a second-year NSF-GE Foundation RAMP-UP graduate Fellow. She received her B.S. in Mathematics from Stony Brook Univeristy in 2004. She entered the Biomathematics program at North Carolina State University and received her M.S. in the summer of 2007. Currently she is a Ph.D. candidate in Biomathematics.

\section{Kate Caldwell, North Carolina State University}

Kate Caldwell received her M.S. in Mechanical Engineering from North Carolina State University in the spring of 2007. She was an NSF-GE Foundation RAMP-UP graduate Fellow during the 2005-2007 academic years.

\section{Jessica McCoy, North Carolina State University} Jessica McCoy received her M.S. in Industrial Engineering from North Carolina State University in the summer of 2007. She was an NSF-GE Foundation RAMP-UP graduate fellow during the 2006-2007 academic year.

\section{Laura Bottomley, North Carolina State University}

\section{Elizabeth Parry, North Carolina State University}

Elizabeth Parry received her B.S. in Engineering Management-Mechanical Engineering from the University of Missouri-Rolla in 1983. After working for IBM for 10 years, Mrs. Parry left to raise her children and start a science education business. Since 1999, she has directed two major grant programs for the College of Engineering at North Carolina State University. Currently, she is the engineering project director for RAMP-UP (Recognizing Accelerated Math Potential in Underrepresented People), a five-year program focusing on outreach to strengthen K-12 math, science and engineering knowledge and funded by NSF and the GE Foundation. 


\title{
The Impact of Out-of-School Time (OST) Math and Science Clubs on Elementary and Middle School Students, Teachers, Schools and the Undergraduate and Graduate Fellows that Facilitate Them
}

\begin{abstract}
Out-of-school time (OST) clubs can positively affect students in grades 3-8 by reinforcing concepts learned during the normal class hours, learning new concepts, and providing an outlet where the children are free to interact more casually with the instructors and their peers. RAMP-UP (Recognizing Accelerated Math Potential in Underrepresented People), a National Science Foundation funded GK-12 outreach program at North Carolina State University (NCSU), has established OST Math Clubs and Energy Clubs at three, local, inner-city elementary schools and Fun Applications in Math and Engineering (FAME) at two middle schools. These clubs are run by undergraduate and graduate RAMP-UP Fellows from North Carolina State University and Shaw University. Having the RAMP-UP Fellows lead the clubs allows the teachers the opportunity to relax, to interact with the children less formally and to learn something new. The hands-on nature of the activities in the clubs lends itself well to encourage, develop and expose the math and science ability (in students) that may not be demonstrated during the regular classroom time. This additional opportunity for students and teachers to interact provides the teacher with a wider view of a student's ability (especially a student from an underrepresented group).
\end{abstract}

Undergraduate and graduate Fellows have also benefited by leading and facilitating the clubs. The paper, "The Impact of K-12 Outreach Programs on Graduate and Undergraduate Experiences," by Kate Caldwell, Jessica McCoy, Lynn Albers, Althea Smith, Elizabeth Parry and Laura Bottomley from the 2007 ASEE Conference showed that through their work with RAMP-UP, undergraduate Fellows have improved their public speaking skills, felt more prepared for their careers, and felt that they were making a difference simply by being positive role models. In addition, by working with OST clubs, the undergraduate Fellows work directly with the graduate Fellow who exposes them to new areas of research, helps strengthen their math and science skills and provides an opportunity to discuss their post-undergraduate plans. Among the NCSU Fellows a much higher percentage of undergraduate Fellows plan to attend graduate or professional school, as compared to similar statistics for the entire university undergraduate population. The graduate Fellow benefits in much the same way and additionally develops managerial and administrative skills.

Out-of-school time science and math clubs in elementary and middle schools not only benefit the children, teachers, undergraduate and graduate Fellows but they also benefit the elementary school, the universities and the communities they support. We will show the impact on 3-8 students and teachers through observation and surveys. We will also survey the undergraduate Fellows and teachers working with the clubs. 


\section{Introduction}

Out-of-school (OST) programs conclusively create greater engagement in learning and higher academic performance. ${ }^{5}$ Moreover, students participating in "good afterschool programs develop interests and skills that stay with them throughout their lives.", RAMP-UP (Recognizing Accelerated Math Potential in Underrepresented People), a National Science Foundation funded GK-12 outreach program at North Carolina State University (NCSU), has established OST Math Clubs and Energy Clubs at three, North Carolina, inner-city elementary schools and Fun Applications in Math and Engineering (FAME) Clubs at two, local, middle schools. Posner \& Vandell (1994) observed that "third-grade children who spent more time doing academic and enrichment activities also had better relations with peers, better conduct grades, and better emotional adjustment at school than children who spent less time in these activities." "Vandell, Reisner and Pierce (2007) concluded that elementary and middle school "students who regularly attended the high-quality afterschool programs (alone or in combination with other activities) across two years demonstrated significant gains in standardized math test scores, compared to their peers who were routinely unsupervised during afterschool hours." 8 They also concluded that "middle school students who regularly participated in high-quality afterschool programs had significant gains in self-reported work habits, relative to unsupervised students." ${ }^{8}$ In this paper we will show that participation in the OST clubs administered by RAMP-UP positively affect students in grades 3-8 by reinforcing concepts learned during the normal class hours, learning new concepts, and providing an outlet where the children are free to interact more casually with the instructors and their peers. The teachers are positively impacted by being inspired to teach newly learned STEM concepts and building better relationships with their students which created a more positive teaching and learning experience during normal class hours. In addition, one teacher commented that the OST Club "increased [their] confidence in math and science." The schools are positively impacted by having a RAMP-UP administered OST club because it creates a more positive image in the community, which translates to a more positive learning attitude by the students.

This study will also illustrate that RAMP-UP administered OST Clubs positively impact the undergraduate and graduate Fellows who create and facilitate these Clubs by helping them learn new teaching and presentation skills. This helped to build self-esteem, which translated into a more positive learning experience in university courses. Currently there does not exist sufficient research on the impact of OST Clubs on university undergraduate and graduate students. Our paper is an attempt to fill this void. We will provide quantitative data from surveys collected that support our claims.

\section{$\underline{\text { Definitions }}$}

For the purpose of this paper, any use of the word "student" refers to a child in grades 38 , any use of the word "Fellow" refers to an undergraduate student from North Carolina State University (NCSU) and Shaw University (Shaw), any use of the word "teacher" refers to a teacher in a Wake County Public School System (WCPSS) school, any use of the words "graduate Fellow" refers to a graduate student from NCSU, any use of the 
word "school" refers to a WCPSS school, and any use of the word "university" refers to NCSU and Shaw. RAMP-UP Fellows and graduate Fellows work in the primary schools when the university semester is in session, which results in a 12-13 week presence in the schools. The schools will be referred to in the following manner throughout this paper: ES1 = Elementary School 1, ES2 = Elementary School 2, ES3 = Elementary School 3, MS1= Middle School 1, MS2 = Middle School 2.

In the section titled, "Description of RAMP-UP and OST Clubs," we provide a full overview of the structure and operation of the RAMP-UP program. We also provide the details for each of the OST Clubs, which include Energy Club, Math Club and FAME. In the section titled, "Impact of RAMP-UP OST Clubs," we report the quantitative results of the surveys collected from students, teachers, Fellows and graduate Fellows.

\section{Description of RAMP-UP and OST Clubs}

\section{$\underline{\text { RAMP-UP Structure and Operation }}$}

RAMP-UP, a partnership between North Carolina State University, Shaw University, and North Carolina's Wake County Public School System, is a five-year program funded by grants from the National Science and GE Foundations. The 2007-2008 program consists of two principal investigators, one engineering project coordinator, two graduate Fellows, 18 Fellows in science, technology, engineering or math (STEM) and secondary math education working with 18 teachers in grades K-12 at six local, public schools (Figure $1)^{2}$

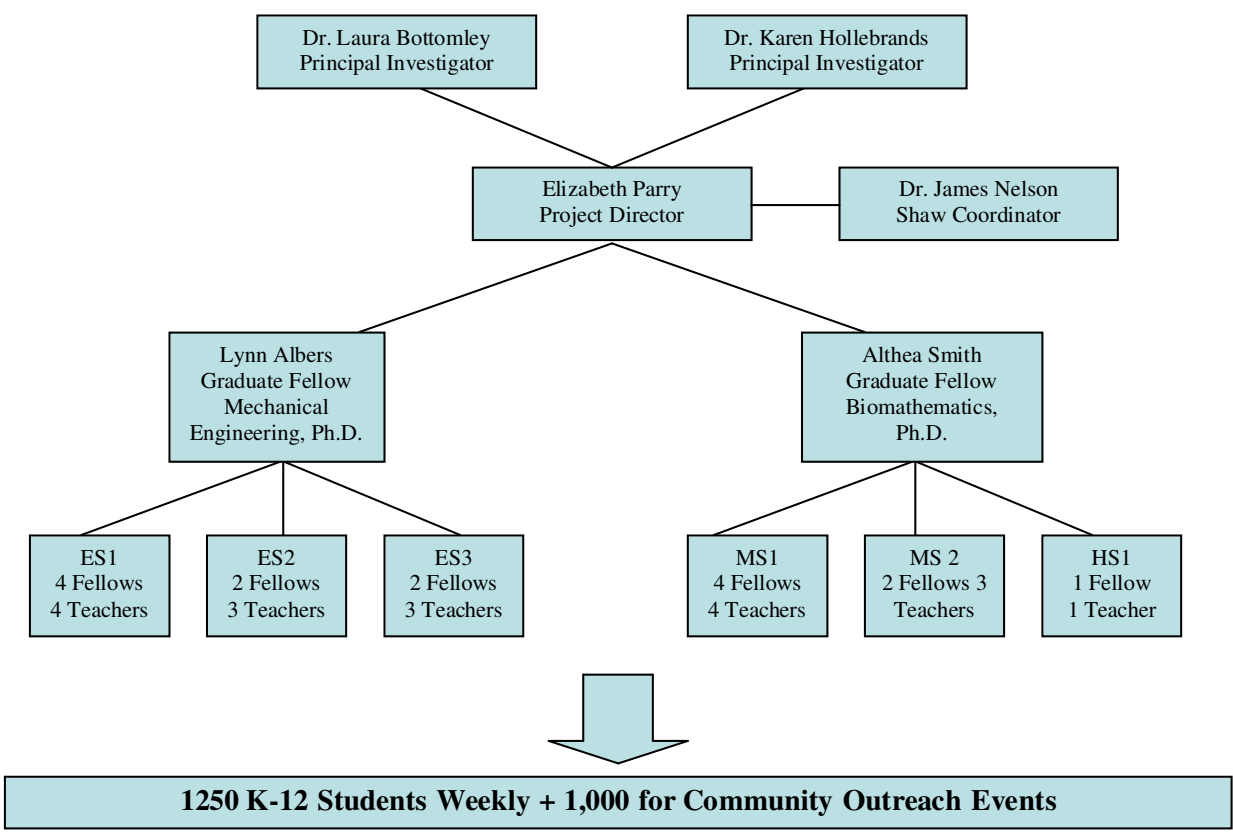

Figure 1. RAMP-UP Organizational Chart for Fall 2007

The engineering project coordinator mentors the two graduate Fellows in learning and 
practicing professional skills (e.g., managerial, administrative). The coordinator and graduate Fellows perform many of the organizational and preparation work together everything from coordinating Family Math Nights to assigning Fellows to schools. Under the direction of the coordinator, graduate Fellows supervise teams of Fellows who work with classroom teachers throughout the academic year. They plan and implement inquiry-based mathematics lessons that demonstrate the practical application of mathematical theory. RAMP-UP Fellows are role models and mentors for their students and thereby have the opportunity to make a significant difference for many K-12 students. The coordinator also serves as a teacher and mentor to the Fellows, many of whom have initially never taught before. The Fellows learn the basics of developing and implementing lesson plans as well as the professional skills inherent in interacting with teachers and their graduate Fellow supervisors. ${ }^{2}$

The graduate Fellows are responsible for implementing the broader aspects of the program such as helping plan seminar lessons, creating surveys, and organizing team building events. They are also responsible for overseeing much of the daily operation of the program. Each graduate Fellow applies managerial and mentoring techniques to 8-10 Fellows across three schools. The Fellows work an average of 8-10 hours per week with up to two teachers at their respective schools. They also run or assist with OST Clubs that reinforce math and science concepts. The Fellows coordinate their work schedules with their respective teachers to maximize their weekly schedule. The graduate Fellows ensure that the Fellow is working with the teacher in math related classes and utilizing their time according to the conditions of the grant through regularly scheduled team meetings and by checking their timesheets against work logs every two weeks. The graduate Fellow also ensures that the partnership between the Fellows, the teachers and their schools is healthy, and that the interaction of the Fellows with the K-12 students remains activity-based. ${ }^{2}$

The inclusion of undergraduates under the supervision of graduate Fellows makes RAMP-UP unique among other GK-12 programs funded by the National Science Foundation. In addition to managing the Fellows, the graduate Fellows are also responsible for the team of RAMP-UP teachers at each school. In past years, a school staff member has served as the liaison between graduate Fellows and teachers to facilitate the daily operations of the program. During the 2007-2008 school year, the graduate Fellow has assumed this responsibility and meets with the team of teachers regularly to make sure the program is being implemented correctly and successfully in their classrooms. They also lead OST Clubs at their schools, open to students who have been identified as needing extra support. ${ }^{2}$

The program targets middle and upper middle ability students who have not been identified by the state as being 'academically gifted' (AG) based on their performance on cognitive ability and basic skills standardized tests administered in the third grade. This AG label is necessary for students to be identified for the university math track. The majority of students currently identified as AG at RAMP-UP schools are white and Asian, which is not representative of the overall school demographics. RAMP-UP Fellows and teachers focus on students who have been identified as 'below grade level' 
but with the potential to achieve grade level proficiency with focused intervention. ${ }^{2}$

RAMP-UP goals target three stakeholder groups: K-12 students, the university undergraduate and graduate Fellows and mathematics teachers in grades K-12. All stakeholders support the overall goal of increasing the number and diversity of students who enroll and succeed in higher-level math courses, specifically algebra by 8th or 9th grade and calculus by 12 th. $^{2}$

\section{Description of OST Clubs}

\section{Energy Club}

The Energy Club is an opportunity for students to meet outside of regularly scheduled class time to learn more about renewable energies, energy conservation and recycling. In the spring of 2007, RAMP-UP began an Energy Club at ES1. It met weekly on Wednesday mornings before school from 7:45 am - 8:45 am. Seven third grade students, four girls and three boys, participated weekly. The graduate Fellow was the primary instructor with assistance from one Fellow and one teacher who recruited the participants via morning announcements. We began by introducing the students to solar energy through hands-on demonstrations with real solar panels. The students responded well to all four lessons covering solar energy. We then moved on to wind energy where we used one of the lessons developed by the Engineering is Elementary team of the Boston Museum of Science titled, "Catching the Wind: Designing Windmills; Air, Weather, and Mechanical Engineering for Elementary Students." "For five sessions, we worked through several of the worksheets, read the story Leif Catches the Wind, and then spent the last 3 sessions of the semester designing and building windmills out of milk cartons, popsicle sticks, index cards, dowels and foam. We divided the Club into smaller groups and each group was videotaped presenting their windmill and its unique design features as shown in Figure 2.

In the fall of 2007, Energy Club at ES1 continued to meet weekly before school from 7:45 am - 8:45 am on Thursdays. The same seven students returned and two new female students joined. The graduate Fellow was the primary instructor with assistance from three Fellows and one teacher. We met twelve times throughout the semester. The first seven lessons focused on energy conservation at home and at school. We primarily focused on lighting and spent several lessons teaching the positive environmental and financial impact of using compact fluorescent lightbulbs instead of incandescent lightbulbs. For example, we estimated that one elementary school uses $56,160 \mathrm{kWh}$ and generates 88,732 pounds of greenhouse gases per year. We then showed that by turning off the cafeteria lights during the day, we could save 3,960 $\mathrm{kWh}$ and 6,256 pounds of greenhouse gases per year in one elementary school. We also showed how these savings are compounded by the fact that there are 96 elementary schools in Wake County. All this was in preparation for the Family Math and Science Night where the Energy Club students explained compact fluorescent lightbulbs and incandescent lightbulbs to peers and their parents. The remaining 5 lessons were spent working an energy Sudoku, and 
performing energy plays provided by The NEED Project titled, "Solar White and the Seven Dwarffuels" and "Energilocks and Close Encounters of the Third Kind.",

During the fall of 2007, RAMP-UP created a second Energy Club at ES2. We had a tremendous amount of interest in the club. The letters announcing the club went home on a Monday and on Tuesday morning at 7 am a parent was knocking on the front door of the school to drop off the student's form in order to ensure their child was accepted into Energy Club. We took the first 20 out of 45 applicants representing grades 3 through 5 . We consistently had 14-18 students participate weekly. The Energy Club met weekly on Monday afternoons from 3:45 pm - 5:00 pm. The club met ten times throughout the semester. The Graduate Fellow was the primary instructor with assistance from two Fellows and the teacher. We followed a similar lesson schedule as ES1. We also spent the last 15 minutes of each lesson collecting the paper recycling for the school. As of February 2008, the Energy Club students have recycled approximately 4,500 pounds of paper.

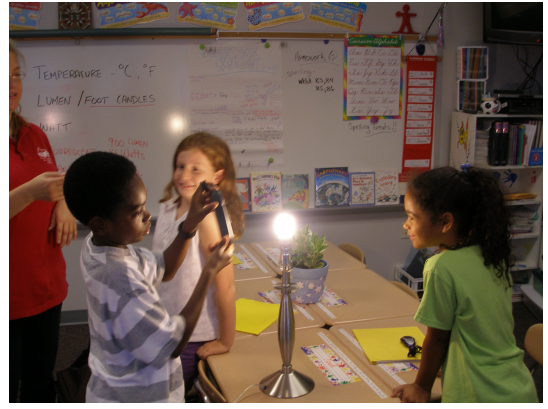

(a)

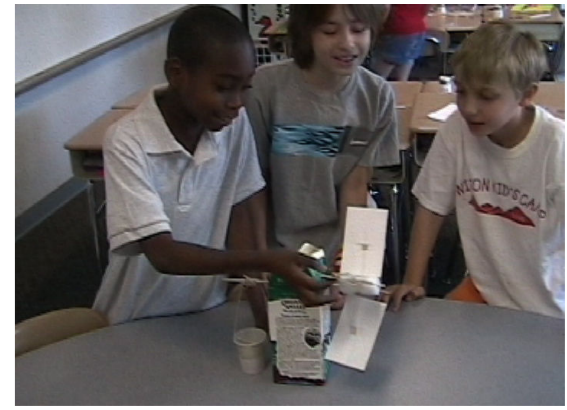

(b)

Figure 2. (a) Graduate Fellow Engaging Students in the Lightbulb Activity, (b) Students Explaining Their Windmill Design

\section{Math Club}

RAMP-UP has conducted several Math Clubs within their participating elementary schools since its inception. The following will focus on the Math Clubs that have been conducted in the fall 2006, spring 2007 and fall 2007 semesters. The Math Clubs are an opportunity for students to meet outside of regularly scheduled class time to reinforce concepts learned during normal class hours, learn new concepts and have fun with math.

In the fall of 2006, RAMP-UP conducted a fourth grade Math Club at ES1. It met weekly on Wednesday afternoons from 3:45 pm - 4:45 pm. The Fellow was the primary instructor with assistance from one teacher, where 10-15 students participated weekly. The same Fellow continued the fourth grade Math Club at ES1 in the spring of 2007.

In the fall of 2007, RAMP-UP conducted a third grade Math Club which met weekly on Tuesday afternoons from 3:45 pm - 4:45 pm and a fourth grade Math Club which met weekly on Thursday afternoons from 3:45 pm - 4:45 pm at ES1. The Fellow (not the same one mentioned above) was the primary instructor with assistance from one teacher 
for both clubs. The Fellow also had assistance from another Fellow and graduate Fellow when their schedules permitted. Thirteen students regularly participated in the third grade Math Club and eight students regularly participated in the fourth grade Math Club. The topics covered in the third grade Math Club consisted of combinations, multi-digit multiplication, order of operations, elapsed time, place value, and algebra. The topics covered in the fourth grade Math Club included probability and estimation, data collection and graphing, perimeter and area, order of operations, conversion, and real life concepts - using a map to determine distances. Many of the lessons for the fourth grade Math Club were created and written by the Fellow from the previous year.

RAMP-UP also conducted three Math Clubs at ES3. A Fellow was the primary instructor with assistance from one teacher for the third grade Math Club which met weekly on Monday afternoons from 3:45 pm - 5:00 pm and with assistance from another teacher for the fifth grade Math Club which met weekly on Wednesday afternoons from 3:45 pm - 4:45 pm. Twelve students regularly participated in the third grade Math Club where they played "Mathquest" which exposes the students to many different topics and problem solving methods. Six students regularly participated in the fifth grade Math Club where the Fellow developed lessons to help the students gain confidence solving math problems. Another Fellow was the primary instructor with assistance from another teacher for the fourth grade Math Club which met weekly on Thursday afternoons from 3:45 pm - 5:00 pm where five students regularly participated. The topics covered included fractions, measurement, multiplication, team building, bridge building and a paper folding activity including a paper airplane design contest. Tables 1, 2, and 3 detail the composition of Energy Club and Math Club at ES1, ES2 and ES3 respectively. The Energy Clubs and Math Clubs will continue in the same capacity in the spring 2008 academic calendar.

Table 1. Description of Energy Club and Math Club held at ES1.

\begin{tabular}{|l|c|l|l|l|l|l|}
\hline ES1 & \multicolumn{2}{|c|}{ Energy Club } & \multicolumn{4}{c|}{ Math Club } \\
\hline $\begin{array}{l}\text { Date } \\
\text { implemented }\end{array}$ & Spring 2007 & Fall 2007 & $\begin{array}{l}\text { Fall 2006 } \\
\text { Fourth Grade }\end{array}$ & $\begin{array}{l}\text { Spring 2007 } \\
\text { Fourth Grade }\end{array}$ & $\begin{array}{l}\text { Fall 2007 } \\
\text { Third Grade }\end{array}$ & $\begin{array}{l}\text { Fall 2007 } \\
\text { Fourth Grade }\end{array}$ \\
\hline $\begin{array}{l}\text { Number of } \\
\text { participants }\end{array}$ & $\begin{array}{l}\text { 1 Graduate } \\
\text { Fellow } \\
1 \text { Teacher } \\
\text { 1 Fellows }\end{array}$ & $\begin{array}{l}\text { 1 Graduate } \\
\text { Fellow } \\
1 \text { Teacher } \\
\text { 3 Fellows }\end{array}$ & $\begin{array}{l}\text { 1 Fellow } \\
\text { 1 Teacher } \\
\text { 1 Fellow }\end{array}$ & $\begin{array}{l}\text { 1 Fellow } \\
\text { 1 Teacher }\end{array}$ & $\begin{array}{l}\text { 1 Fellow } \\
1 \text { Teacher }\end{array}$ \\
\hline $\begin{array}{l}\text { Average } \\
\text { number of } \\
\text { students / } \\
\text { session }\end{array}$ & 7 & 9 & 16 & 16 & 13 & 8 \\
\hline $\begin{array}{l}\text { Number of } \\
\text { sessions held }\end{array}$ & 12 & 12 & 12 & 12 & 12 & 12 \\
\hline
\end{tabular}

Table 2. Description of Energy Club held at ES2.

\begin{tabular}{|l|l|}
\hline ES2 & Energy Club \\
\hline Date implemented & Fall 2007 \\
\hline Number of participants & 1 Graduate Fellow \\
& 1 Teacher \\
& 2 Fellows \\
\hline Average umber of students / session & \multicolumn{1}{|c|}{16} \\
\hline
\end{tabular}


Table 3. Description of Math Club held at ES3

\begin{tabular}{|l|l|l|l|}
\hline ES3 & \multicolumn{3}{|c|}{ Math Club } \\
\hline Date implemented & $\begin{array}{l}\text { Fall 2007 } \\
\text { Third Grade }\end{array}$ & $\begin{array}{l}\text { Fall 2007 } \\
\text { Fourth Grade }\end{array}$ & $\begin{array}{l}\text { Fall 2007 } \\
\text { Fifth Grade }\end{array}$ \\
\hline Number of participants & $\begin{array}{l}\text { 1 Fellow } \\
1 \text { Teacher }\end{array}$ & $\begin{array}{l}\text { 1 Fellow } \\
1 \text { Teacher }\end{array}$ & $\begin{array}{l}\text { 1 Fellow } \\
1 \text { Teacher }\end{array}$ \\
\hline Average number of students / session & 12 & 5 & 6 \\
\hline Number of sessions held & 12 & 12 & 12 \\
\hline
\end{tabular}

\section{Fun Applications of Math and Engineering (FAME)}

FAME was created in the fall of 2006 by a RAMP-UP graduate Fellow. This program is an opportunity to help students with understanding key math concepts, and to involve students in fun, hands-on math and engineering related group activities.

FAME was first developed as a pilot program at a local middle school (MS1). For 60 minutes each week, roughly ten students participated in this program. Each session was administered by a graduate Fellow, two Fellows, and one math teacher. The topics covered during this pilot program included algebra, geometry, and basic physics of motion and force. During the activities students learned accurate measurement techniques, algebraic relationships, graphing skills and how to interpret their collected data. For example, at one session the students learned how engineers construct sturdy buildings in the activity "Polyhedra Earthquake". Students were first introduced to the concept of regular polyhedra and instructed to build a sturdy building from toothpicks and marshmallows to withstand an earthquake simulated in a pan of Jell-O. Unfortunately, the school day at MS1 begins very early in the morning and interest for this after-school program waned towards its conclusion. However, there may have been other reasons why participation in this program declined. Regardless of the this lack of interest, RAMP-UP decided to no longer continue FAME at MS1. No data for FAME at MS1 was collected and thus we will not present quantitative data on this program at MS1.

RAMP-UP expanded FAME to a second local middle school (MS2) and it was continued there through the fall of 2007. In the spring semester, the program was administered by one graduate Fellow, two Fellows, and one math teacher. On average, 18 students regularly participated. Due to the success of the program in the spring, the number of students regularly participating doubled to 40 in the fall. Because of this increase, the program enlarged its staff to one graduate Fellow, four Fellows and two math teachers (on a rotating schedule).

Weekly, FAME at MS2 was held from 3:20 pm - 4:50 pm on Wednesdays. The first 50 minutes were allotted for the tutorial, where students received help with homework and understanding core mathematical concepts. The remaining 40 minutes were dedicated to the engineering activity. Similar to FAME at MS1, the activities covered algebra, geometry, and core physics principles. The students also learned the key principles of design, how to collect data, estimation, and how to use measurement tools accurately. 
For example, in the activity "Paper Towers", the students were instructed to design a tower out of paper, string, straws, tape, and popsicle sticks. The requirements were that the tower needed to be at least 18 inches tall, made from paper, and be able to withstand the weight of a tennis ball. (This activity was modified from the PBS DESIGN SQUAD activity, "High Rise". ${ }^{3}$ ) In the second week of this activity, the students were given the additional challenge of designing the tower while keeping the cost of materials within a certain budget. The conditions were that each type of material had a price and the students only had a budget of ten dollars to redesign their tower under the above building guidelines. The majority of the students were highly engaged in this activity. When 24 regularly (attended more than one session) attending students were surveyed at the end of fall $2007,45.8 \%$ of them said that they enjoyed this activity the most.

FAME will continue operating at MS2 for the spring 2008 academic calendar. Table 1.4, details the composition of FAME at MS1 and MS2.

Table 4. Description of FAME held at MS1 and MS2.

\begin{tabular}{|c|c|c|c|}
\hline & \multicolumn{3}{|c|}{ FAME } \\
\hline Date implemented & $\begin{array}{l}\text { Fall } 2006 \\
\text { (MS1) }\end{array}$ & $\begin{array}{l}\text { Spring } 2007 \\
(\mathrm{MS} 2)\end{array}$ & $\begin{array}{l}\text { Fall 2007 } \\
(\mathrm{MS} 2)\end{array}$ \\
\hline Number of participants & $\begin{array}{l}1 \text { Graduate Fellow } \\
1 \text { Math Teacher } \\
2 \text { Fellows }\end{array}$ & $\begin{array}{l}1 \text { Graduate Fellow } \\
1 \text { Math Teacher } \\
2 \text { Fellows }\end{array}$ & $\begin{array}{l}\text { 1 Graduate Fellow } \\
2 \text { Math Teachers } \\
4 \text { Fellows }\end{array}$ \\
\hline $\begin{array}{l}\text { Average number of } \\
\text { students / session }\end{array}$ & $\begin{array}{c}10 \\
\left(6-8^{\text {th }} \text { graders }\right)\end{array}$ & $\begin{array}{c}18 \\
\left(6-8^{\text {th }} \text { graders }\right)\end{array}$ & $\begin{array}{c}35 \\
\left(6-8^{\text {th }} \text { graders }\right)\end{array}$ \\
\hline Number of sessions held & 6 & 7 & 7 \\
\hline
\end{tabular}

\section{Impact of RAMP-UP OST Clubs}

RAMP-UP has primarily conducted surveys as a means of collecting data and providing feedback on the impact of the program. For this paper, two surveys were performed. In the first survey, 29 FAME students at MS2 were asked questions to obtain their opinions on math and their perception of the Club during the fall of 2007. Some questions had responses of "yes, some, or no" while other questions were based on a Likert scale $(1=$ strongly disagree, $2=$ disagree, $3=$ neither agree or disagree, $4=$ agree $5=$ strongly agree). In the second survey, 18 teachers, 6 Fellows and 2 graduate Fellows were surveyed in the spring of 2008. For the majority of the questions asked in this survey, our data shows that there is no statistically significant difference between surveying the two subgroups (teachers and Fellows); see Table 5 in the appendix. Of the teachers surveyed, all had one student (whom they based their responses on) in their daily classroom who participated in an OST. Three teachers surveyed were directly involved either with an Energy Club, a Math Club or FAME. The Fellows surveyed were either facilitators of their own Math Club(s) or assisted the two graduate Fellows in FAME or Energy Club. This survey was designed to capture the perspective of each person filling out the survey with respect to the student, the teacher, the school, the Fellow or the graduate Fellow. For example, if a Fellow were filling out the survey, then they would think about their students in the OST Club when answering the question, "Does 
participation in the OST Club positively affect the students by building confidence in science, technology, engineering and math fields?" Each question was followed up by another question such as, "Does this translate to a more positive learning experience during normal class hours?" The Likert scale used for each question was $1=$ not at all, 2 $=$ not much, $3=$ some, $4=$ a little, $5=$ a lot. The average responses for each question ranged from 3.06 to 4.91 . The overall results of this survey are presented in the appendix (Figure 11).

\section{The Impact of OST Clubs on Students, Teachers and Schools}

\section{Students and Teachers}

In the first survey, when the students were asked if they attend this program in order to improve their grades, their average response was 3.78. Moreover, an average of 2.33 on the same Likert scale was obtained when students where asked if they attend FAME in order to socialize with their friends. The students' attitudes towards math in general were accessed and are noted in Figure 3. On average, the students agreed that they can get good grades in math (3.74) and were assured that they can learn math (3.97). However, these results do not imply that the FAME program has an impact on the students' attitudes towards mathematics, but mainly serve to signify pre-existing attitudes. In the future we will use this data as a pre-survey and reexamine the students' attitudes towards math in the spring of 2008 with a post-survey.

According to Bouffard et al. "Linkages between OST and universities can facilitate the postsecondary transition by educating youth about their options for the future and preparing them to apply and to succeed in college"1. During FAME, $96.5 \%$ of these students surveyed said that they enjoyed working with the Fellow. In addition, $86.2 \%$ of the students said that they are more interested in attending college after working with a Fellow and $72.4 \%$ were more interested in studying, math science or engineering after working with the Fellows (Figure 4). 


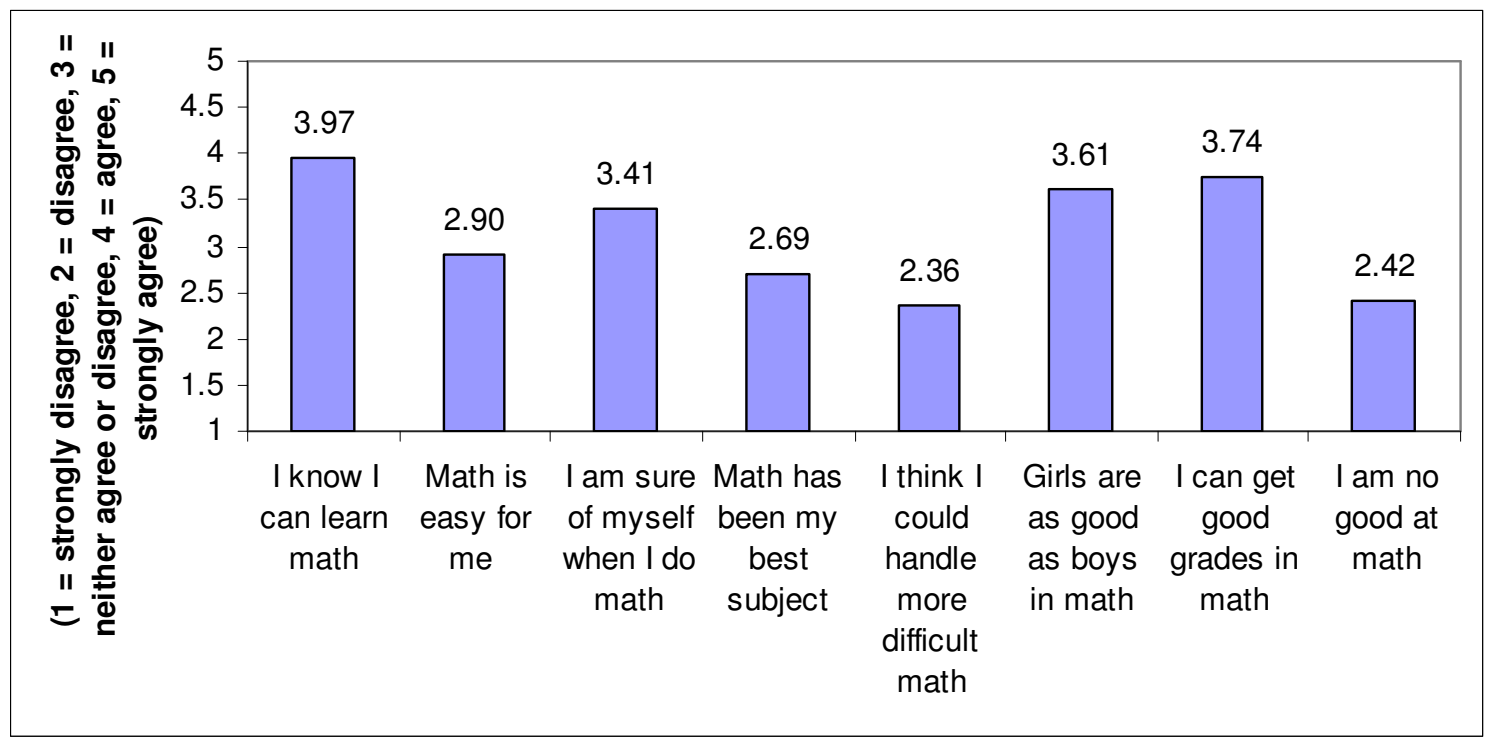

Figure 3. Attitudes Towards Math for Students Participating in FAME at MS2 (N = 29)

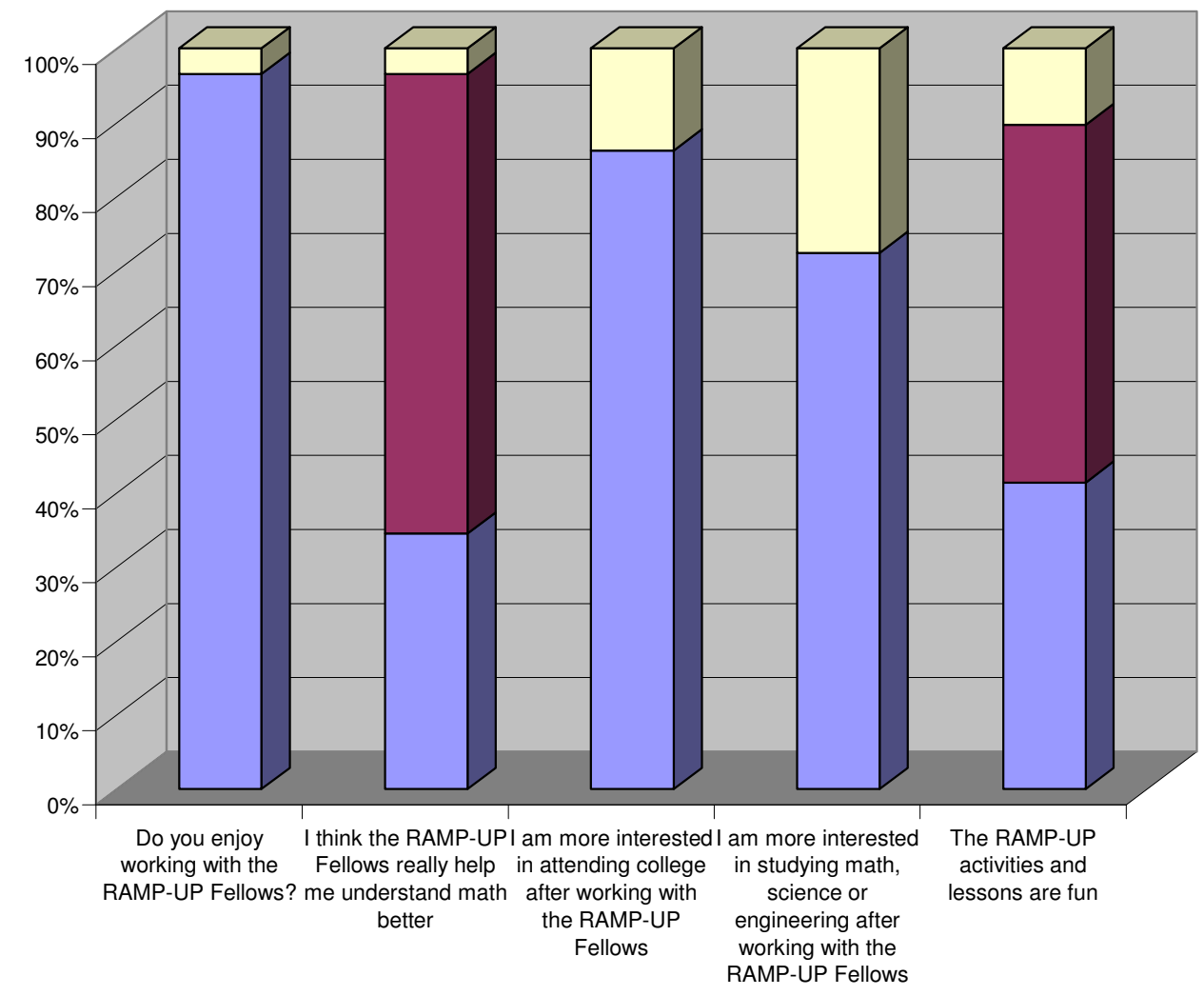

Figure 4. Attitudes of Students Towards Fellows and Activities During FAME at MS2 ( $\mathbf{N}=29)$ 
The average responses to the second survey fell into two categories. The first category reflects the impact of the OST Clubs on the students' and teachers' knowledge and growth in science, technology, engineering, and math (STEM) fields (Figure 5). The second category reflects the impact of the OST Clubs on the students' and teachers' relationships in the academic environment (Figure 6).

\section{Does Participation in an OST Club Positively Affect the Students or Teachers...}

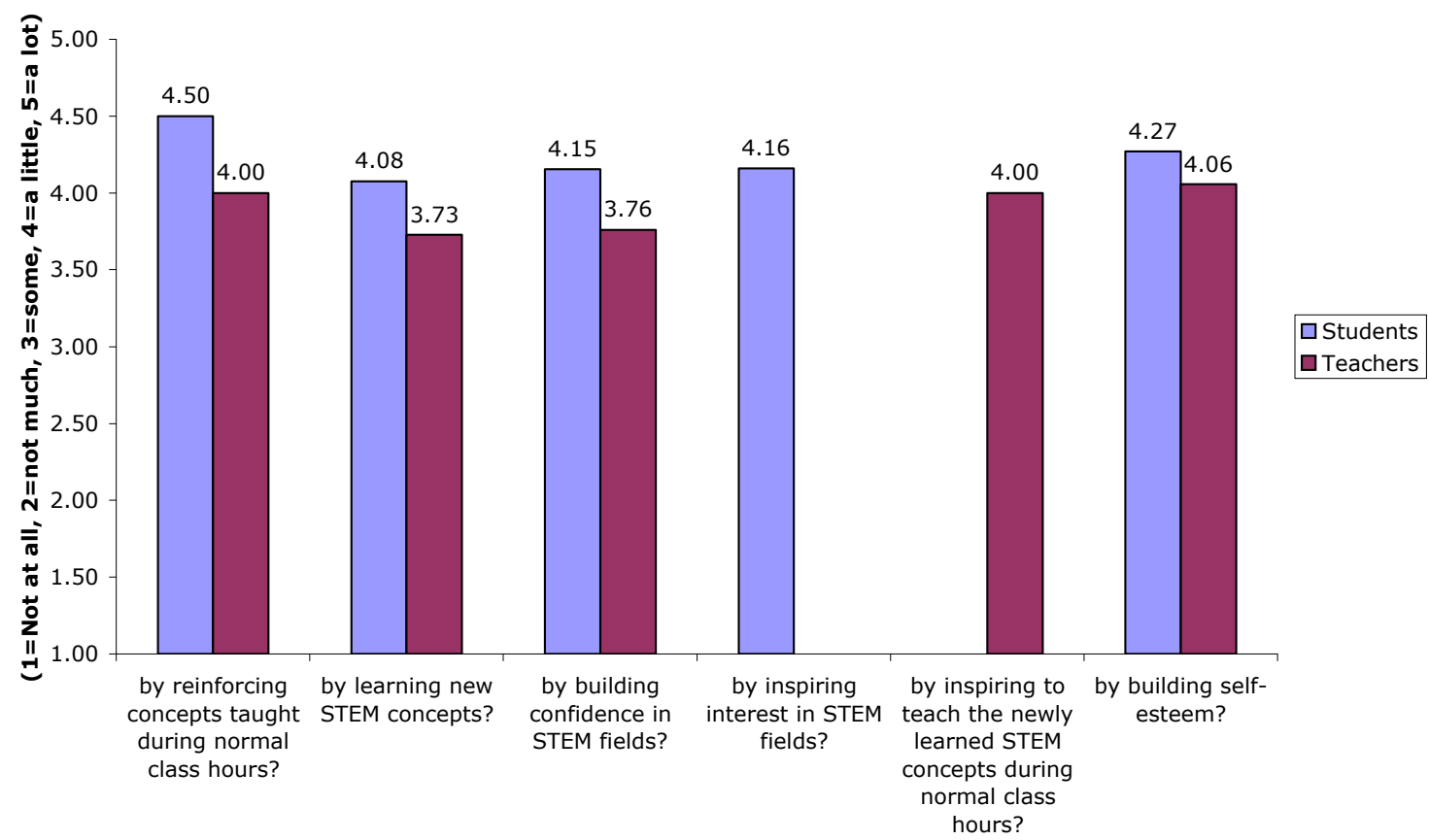

Figure 5. The Impact of OST Clubs on Students' and Teachers' STEM Knowledge

One teacher noted, "The most beneficial part of the OST Club is having students from our school given the opportunity to extend what is learned in class in a different setting and with a potential role model from a local university." Figure 5 shows that those surveyed strongly felt that the OST Club was positively affecting students by reinforcing concepts taught during normal class hours, by building self-esteem and by building confidence in STEM fields each of which had average responses of 4.50, 4.27 and 4.15 respectively. One teacher commented that they noticed an improvement in the learning attitude and classroom participation of a (female) student who "has come out of her quiet and become more assertive and confident" as a result of her participation in the OST Club. Another teacher stated, "I have noticed the student I have has had an attitude change towards science. He appears to have more of an interest in that subject." Yet another teacher commented, "Students who participate in the afterschool program tend to emerge as leaders in math class."

Those surveyed felt that the OST Club helped to inspire interest in STEM fields in students (4.16) and inspire teachers to teach the newly learned STEM concepts during normal class hours (4.00). One Fellow commented that the most benefit to the student 
was "getting exposure to fun math/engineering activities to help them realize they can be good at math and enjoy math." One teacher commented, "They [the students] learn in fun ways (that are hands-on) about topics that are currently important. They carry their knowledge to family and friends, etc. They become more excited about science and math." Does Participation in an OST Club Positively Affect the Students or
Teachers...

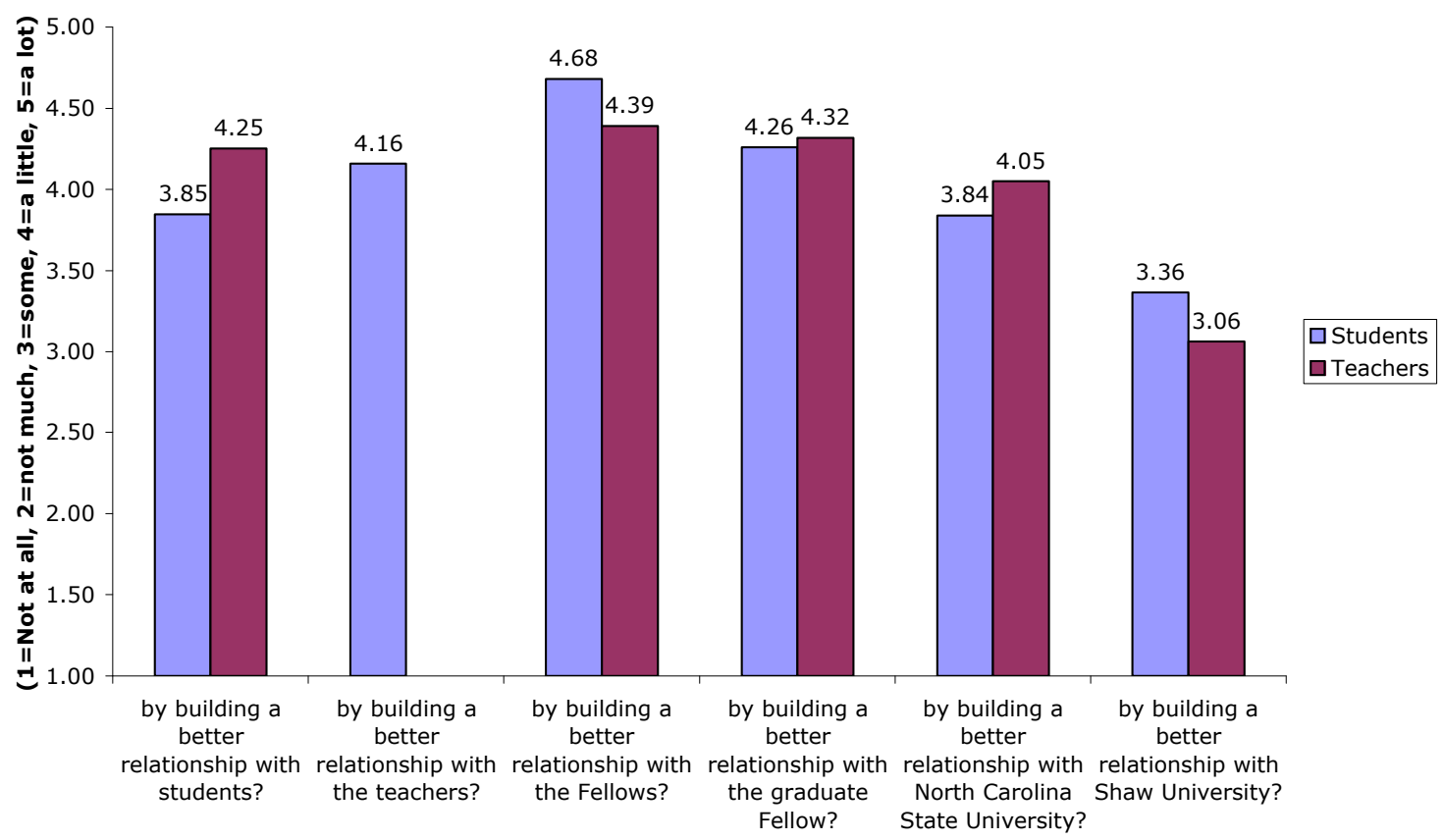

Figure 6. The Impact of OST Clubs on Students' and Teachers' Relationships

Figure 6 illustrates that the OST Club helps to build a better relationship between the Fellows and the students (4.68) and between the Fellows and the teachers (4.39). This improved relationship translated positively into a better learning experience during normal class hours for the student (4.39) and a better teaching experience during normal class hours for the teacher (4.11). One teacher commented, "They [the students] get to interact with college students and "do math" in fun ways which will keep them interested in math." One teacher felt that the most beneficial part of having an OST Club was "the chance it gives the students to interact with peers and Fellows."

Those surveyed felt that the OST Club afforded teachers the opportunities to build a better relationship with their students (4.25) and vice versa (4.16). This better relationship with the student created a more positive teaching experience (4.11) and a 
more positive learning experience (4.26) during normal class hours. As one teacher commented, "I have seen a sense of pride as being part of the OST Club and more participation."

Those surveyed felt that teachers and students were able to build a better relationship with NCSU (4.05 and 3.84 respectively) and with Shaw (3.36 and 3.06 respectively). Students and teachers were unable to build as good a relationship with Shaw because there is only one Fellow from Shaw in the program and they were only able to assist with one club (due to class schedules and transportation issues).

\section{School}

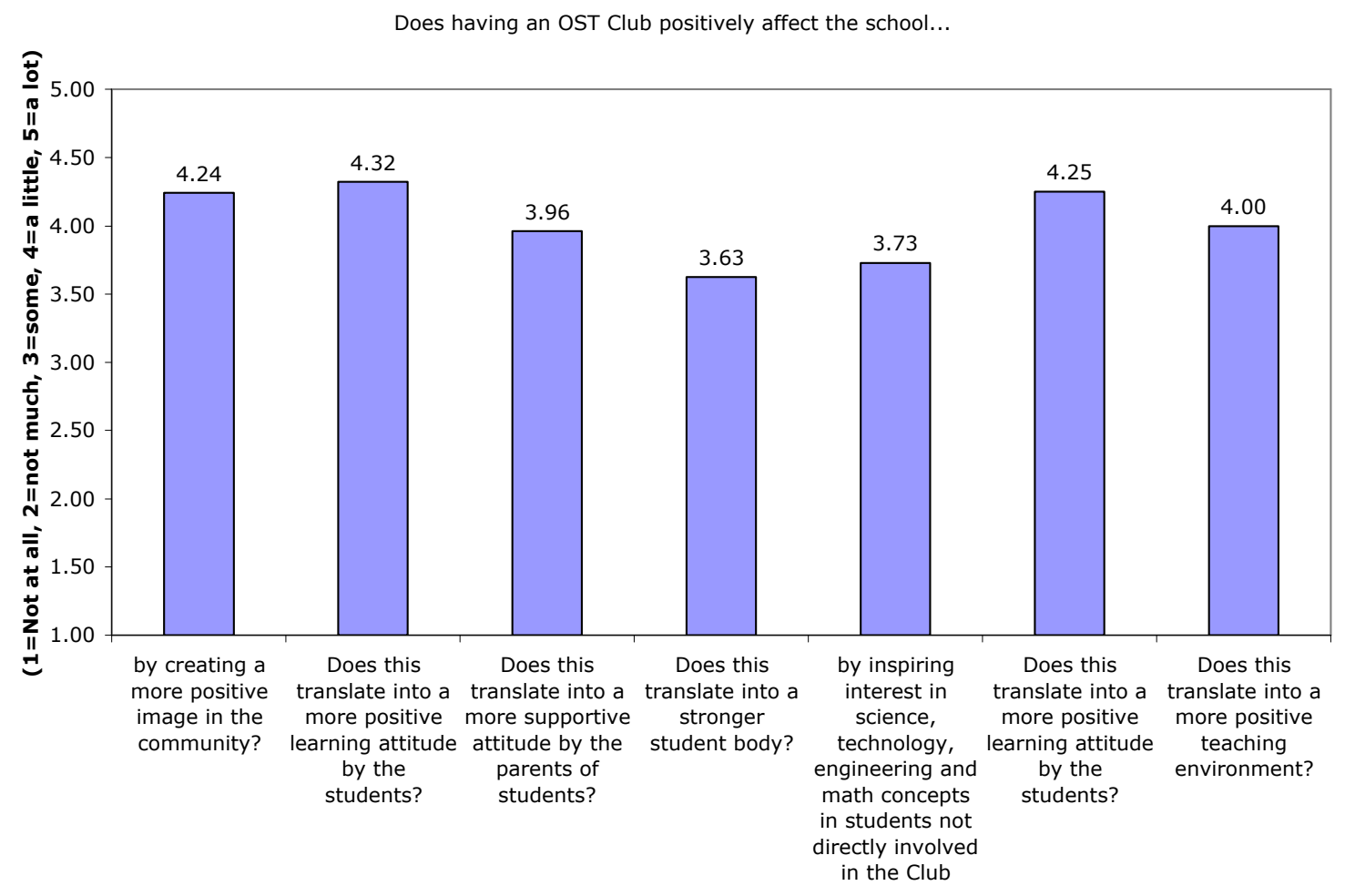

\section{Figure 7. The Impact of OST Clubs on Schools}

Many surveyed felt that the most valuable part of having an OST Club in the school was that it provided another resource for the students to develop math and science skills (Figure 7). The data shows that the OST Club also creates a more positive image in the community (4.24), which translates into a more positive learning attitude by the students (4.32), a more supportive attitude by the parents of students (3.96) and a stronger student body (3.63). One teacher commented that the OST Club "Lets the community know we are invested in helping students learn." One graduate Fellow commented that, "The school benefits by offering a new and unique afterschool program to its students." 
The OST Club also inspires interest in STEM concepts in students and teachers not directly involved in the Club (3.73). One teacher commented that, "The students have created an awareness in the faculty and staff for energy conservation and recycling." One Fellow commented, "If we have done an activity or learned something in the OST Club, students like to bring up these topics in class." This interest in STEM concepts also translates into a more positive learning attitude by the students (4.25) and a more positive teaching environment (4.00).

The Impact of OST Clubs on Fellows, graduate Fellows and the university

\section{Fellows and graduate Fellows}

The questions and average responses with respect to the Fellows and graduate Fellows fell into three categories: personal development (Figure 8), educational relationships (Figure 9), and STEM knowledge (Figure 10).

\section{Does Participation in an OST Club Positively Affect the Fellows or Graduate Fellows...}

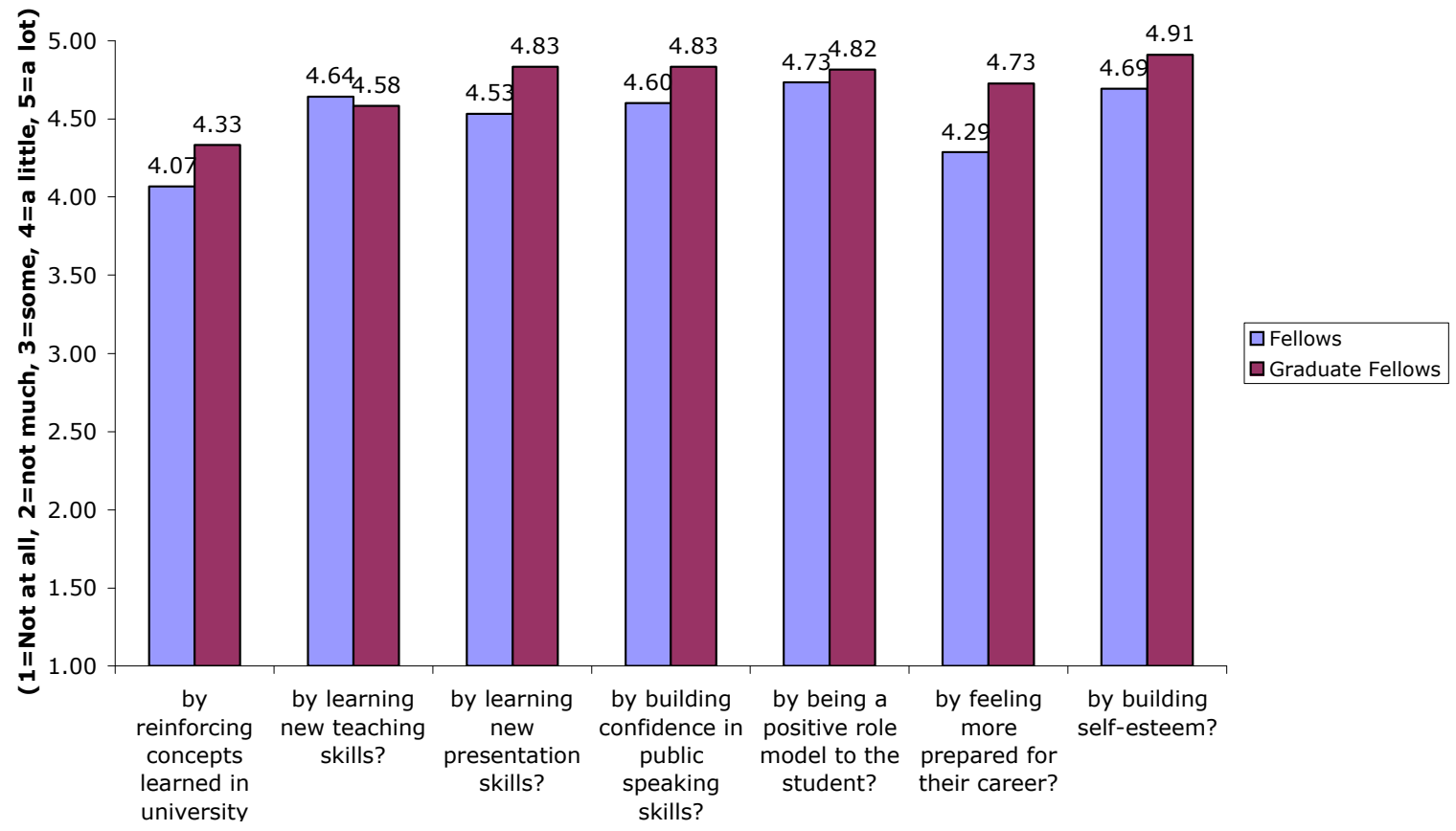

Figure 8. The Impact of the OST Club on Fellows' and Graduate Fellows' Personal Development

One Fellow commented that the most beneficial aspect of participating in an OST Club was "Learning how to teach or explain something to a group of individuals who are not familiar with a certain subject." This sentiment is reinforced by the average responses of 
4.64 and 4.58 for the Fellows and graduate Fellows respectively which translates into a more positive learning experience in university courses (4.33 for Fellows and 4.50 for graduate Fellows). Another Fellow likes how the OST Club "Gives me pre-professional experience in working with students in math." Thereby helping the Fellow feel more prepared for their career as reflected by the average response of 4.29. Those surveyed also felt that participation in the OST Club helped to build confidence in public speaking skills in the Fellows (4.60) and the graduate Fellows (4.83). A Fellow commented, "It [the OST Club] has helped me build confidence and really learn how to manage my time." Another Fellow commented, "As an undergraduate Fellow in education, the most beneficial part for me was getting practice in front of a group of students by myself."

\section{Does Participation in an OST Club Positively Affect the Fellows or Graduate Fellows...}

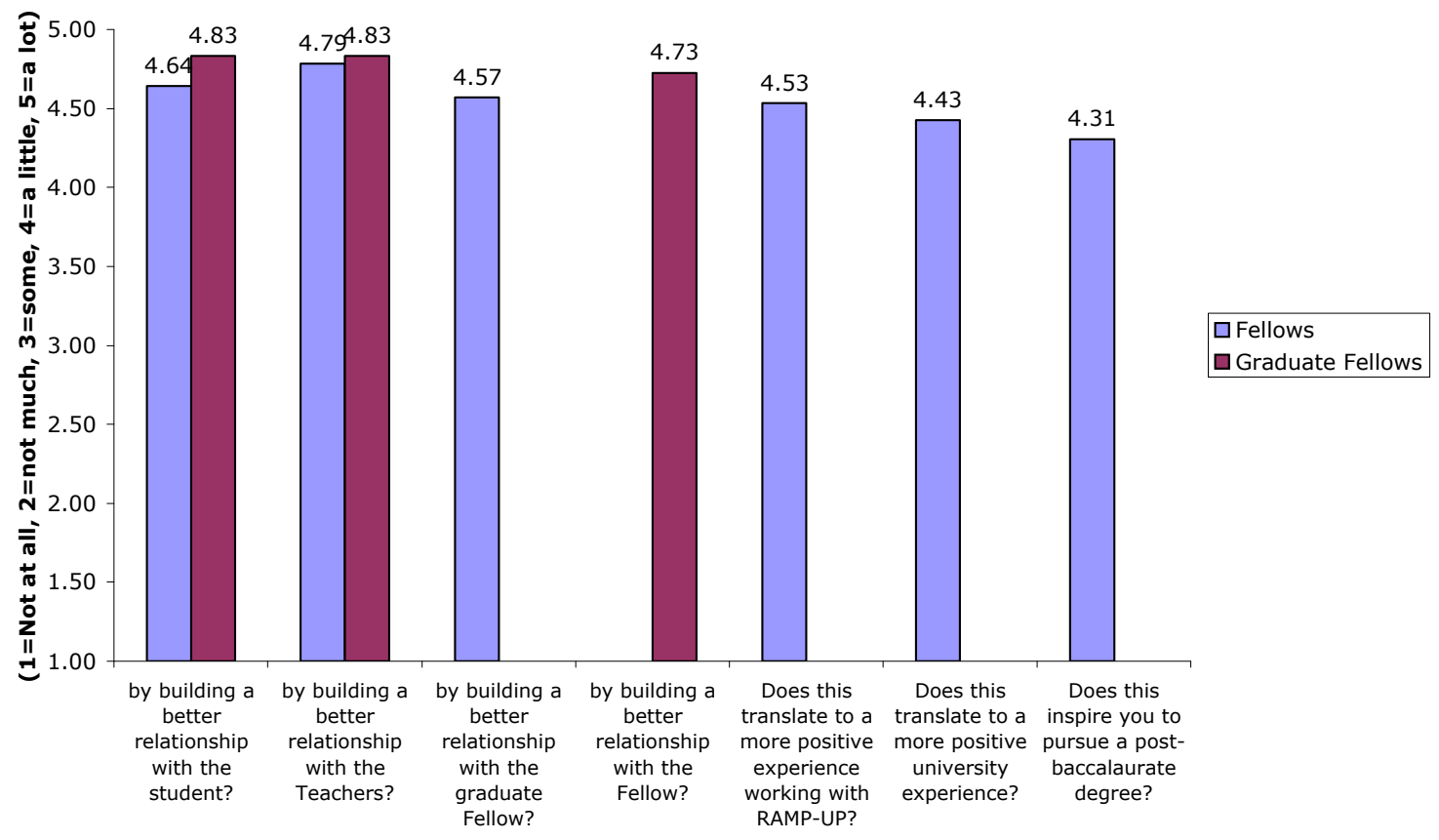

Figure 9. The Impact of OST Clubs on the Fellows' and graduate Fellow's Educational Relationships

The average responses of the impact of the OST Club on the Fellows' and graduate Fellows' educational relationships is documented in Figure 9. The data reflects that the OST Club positively affects the Fellow by building a better relationship with the graduate Fellow (4.57). This improved relationship translates to a more positive experience working with RAMP-UP (4.53), a more positive university experience (4.43) and inspires the Fellow to pursue a post-baccalaureate degree (4.31). All responses were greater than four thereby confirming that the Fellow's relationship with the graduate Fellow is significant. Moreover, one Fellow stated that their graduate Fellow encourages and inspires them to pursue an MD. These results supports RAMP-UP previous years findings' in which $67.4 \%$ of the Fellows in the program planned to go to graduate school as compared to $46.8 \%$ for the total university population. ${ }^{2}$ 


\section{Does Participation in an OST Club Positively Affect the Fellows or Graduate Fellows...}

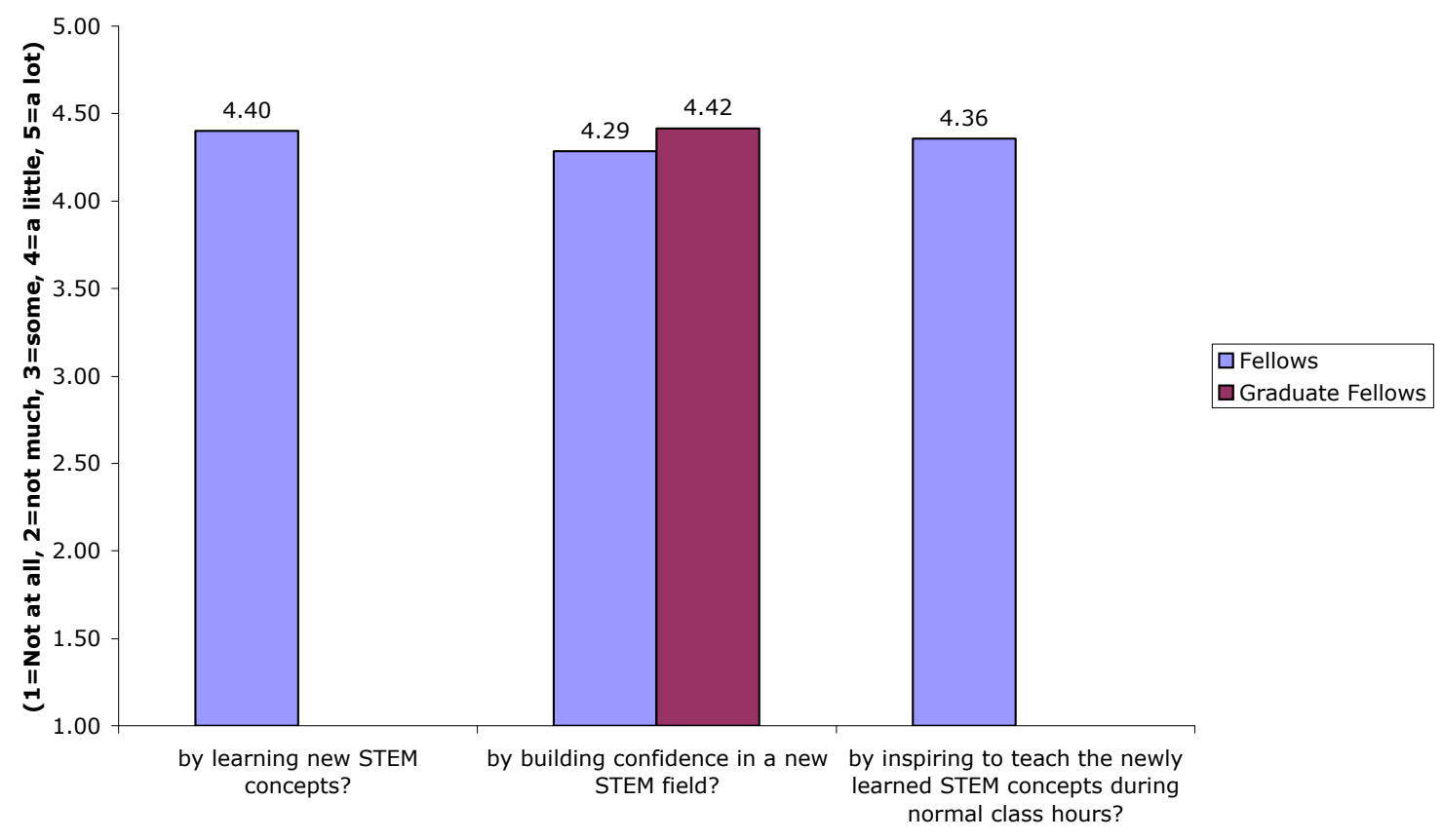

\section{Figure 10. The Impact of OST Clubs on the Fellows' and Graduate Fellows' STEM Knowledge}

The average responses of the impact of the OST Club on their STEM knowledge is displayed in Figure 10. Note that there were two additional questions not asked with respect to the graduate Fellow. These two questions did not apply to the graduate Fellow since in all cases, the graduate Fellow is the subject matter expert and is the one who is teaching the new STEM material in the OST Club.

The data reflects that Fellows (4.29) and graduate Fellows (4.42) are gaining confidence in a new STEM field. One graduate Fellow felt that the most beneficial part of participating in an OST Club is "The chance to educate students and Fellows in areas of science and engineering that they wouldn't normally be exposed to."

\section{University}

One teacher felt that the OST Club "Brings awareness to the college environment and gives students a chance to work with and ask questions to make learning relevant." One graduate Fellow commented that, "The university benefits by having students [Fellows and graduate Fellows] in the community sharing their knowledge gained from courses and professors at the university. This reflects positively on the university by showing that the students [Fellows and graduate Fellows] are well educated." In addition one 
Fellow commented, "It puts the university's name out to the community in a positive light. It shows that members of the university are contributing if even a little bit to the surrounding community." We also found that the teachers surveyed thought that Fellows were role models to their students. One teacher wrote, "It allows college students to learn about being leaders for the generation after them." Another teacher wrote, "It provides an opportunity for fellows and grad students to share an area which they are planning to be experts." One teacher commented, "Energy Club lets the students [Fellows and graduate Fellow] utilize their knowledge to help the students develop their love for science and math."

\section{Conclusion}

Overall, participation in RAMP-UP administered OST Clubs positively impacted the students, teachers, schools, Fellows, graduate Fellows and university in many ways. For the students and teachers involved, our data reflects that the OST Clubs reinforced concepts learned during normal class hours, increased STEM knowledge and improved relationships between students and teachers which translated into more positive teaching and learning environments. $86.2 \%$ of middle school students surveyed admitted that they were more interested in attending college and $72.4 \%$ were more interested in studying math, science or engineering after working with a Fellow during FAME at one middle school. These findings complement the work of Vandell, Reisner and Pierce. Our data also supports the claims of Posner and Vandell in that students build better relationships with their peers, as well as their teachers, Fellows, graduate Fellow and university as a result of their participation in the OST. Our findings also reveal that the teachers were inspired to teach newly learned STEM concepts and built better relationships with the Fellows, graduate Fellows and university; all of which had positive impacts in the classroom and on the school.

Furthermore, the data supports the claim that RAMP-UP administered OST Clubs positively impact the Fellow and the graduate Fellow. This impact is shown in increased confidence in public speaking skills, in a feeling of preparedness for careers, learning of new STEM concepts and building self-esteem. The OST Club also gives the Fellow the opportunity to build a stronger relationship with the graduate Fellow, corresponding to a more positive university experience and potential enrollment in post-baccalaureate studies.

One teacher commented that, "It [the OST Club] has helped students become identified in the area of math for various academically gifted (AG) services." While this comment is outside the scope of this report, it is worth noting as a sidebar that the underlying goal of RAMP-UP is to recognize accelerated math potential in underrepresented people. So it is very encouraging, and worth investigating in the further whether the OST Club provides an additional avenue to accomplish this. 


\section{Acknowledgements}

The authors would like to thank all of the former and current RAMP-UP Fellows and teachers who have participated in this study and who continue to dedicate themselves to K-12 outreach through RAMP-UP.

\section{References}

1. Suzanne Bouffard, Priscilla Little and Heather Weiss. Building and Evaluating Out-of-School Time Connections, The evaluation exchange. Harvard Family Research Project Volume XII Numbers 1\&2, Fall 2006.

2. Kate Caldwell, Jessica McCoy, Lynn Albers, Althea Smith, Elizabeth Parry, and Laura Bottomley. The Impact of K-12 Outreach Programs on Graduate and Undergraduate Experiences, Proceedings of the 2007 American Society for Engineering Education Conference, June 2007.

3. DESIGN SQUAD produced by WGBH Educational Foundation. PBSkids.org DESIGN SQUAD. 2008. $<$ http://pbskids.org/designsquad/parentseducators/activities/index.html>.

4. Engineering is Elementary of the Boston Museum of Science. EiE: Engineering Technology Lessons for Children! 2008. <http://www.mos.org/eie/index.php>.

5. Beth M. Miller. Critical Hours: Afterschool Programs and Educational Success, Report Commissioned by the Nellie Mae Education Foundation, May 2003.

6. National Energy Education Development Project. The NEED Project - Putting Energy into Education. 2007. <http://www.need.org/curriculum.php>.

7. Jill K. Posner and Deborah Lowe Vandell. Low-income children's after-school care: Are there beneficial effects of after-school programs?, Child Development 65 (1994): 440-456.

8 Deborah L. Vandell, Elizabeth R. Reisner, and Kim M. Pierce. Outcomes Linked to High-Quality Afterschool Programs: Longitudinal Findings from the Study of Promising Afterschool Programs, Report Supported by the Charles Stewart Mott Foundation, October 2007. 


\section{Appendix}

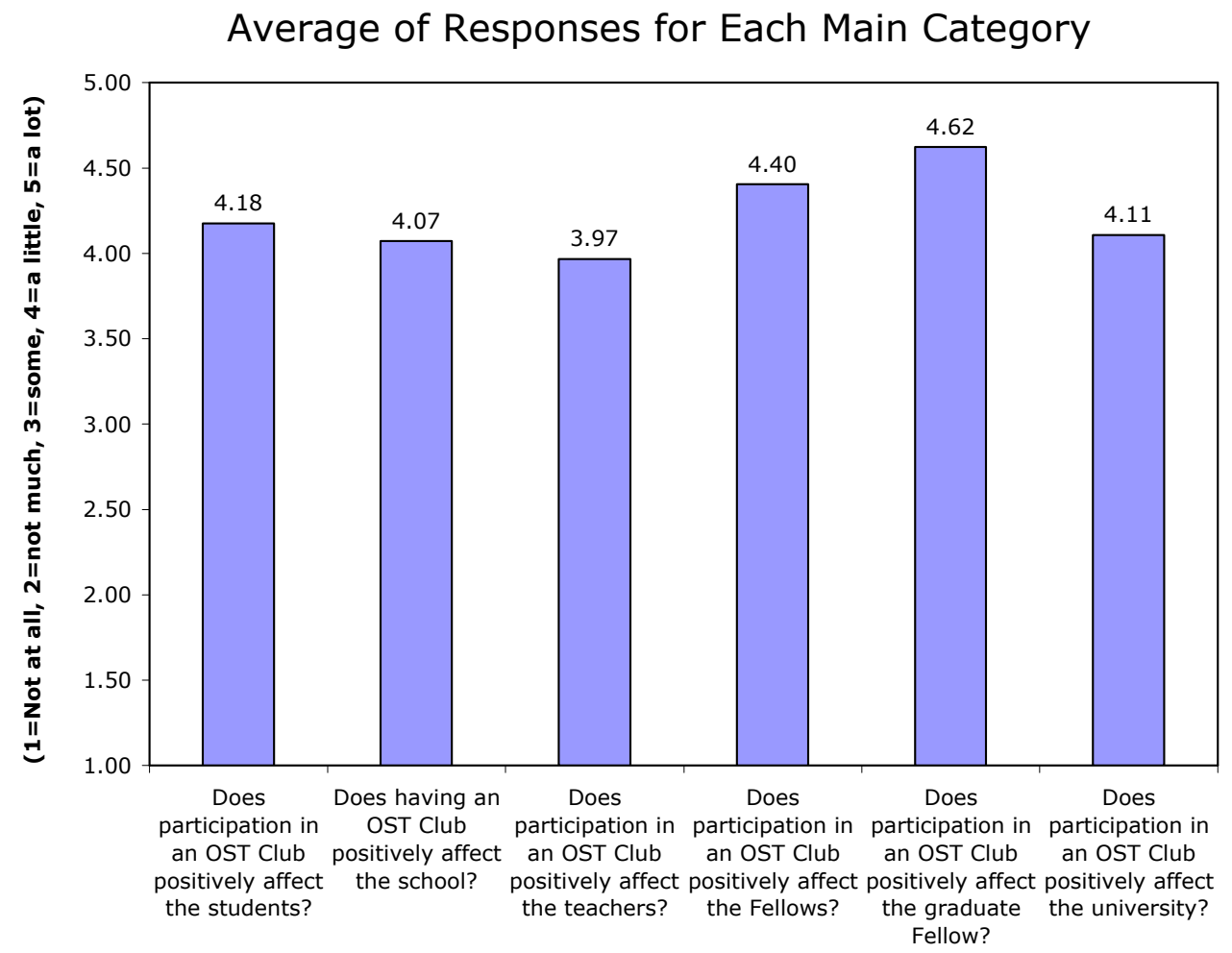

Figure 11. Impact of OST Club on the students, school, teachers, Fellows, graduate Fellows and university. 
Table 5. Second survey data divided into two subgroups: Fellows and Teachers.

\begin{tabular}{|c|c|c|c|c|c|c|c|}
\hline & & \multicolumn{2}{|c|}{ Teachers $(\mathrm{N}=20)$} & \multicolumn{2}{|c|}{ Fellows $(\mathrm{N}=6)$} & \multicolumn{2}{|c|}{ Two-sided t-test } \\
\hline Question & & Average & $\begin{array}{l}\text { Standard } \\
\text { Deviation }\end{array}$ & Average & $\begin{array}{l}\text { Standard } \\
\text { Deviation }\end{array}$ & t-statistic & p-value \\
\hline \multirow{12}{*}{$\begin{array}{c}\text { Does } \\
\text { participation in } \\
\text { an OST Club } \\
\text { positively affect } \\
\text { the students or } \\
\text { teachers... }\end{array}$} & $\begin{array}{l}\text { by reinforcing } \\
\text { concepts learned } \\
\text { during normal } \\
\text { class hours? }\end{array}$ & 4.45 & 0.60 & 4.67 & 0.52 & -0.86 & 0.41 \\
\hline & $\begin{array}{l}\text { by learning new } \\
\text { STEM concepts? }\end{array}$ & 4.15 & 1.04 & 3.83 & 0.98 & 0.68 & 0.51 \\
\hline & $\begin{array}{l}\text { by building self- } \\
\text { esteem? }\end{array}$ & 4.50 & 0.69 & 3.50 & 0.84 & 2.67 & 0.03 \\
\hline & $\begin{array}{l}\text { by inspiring } \\
\text { interest in STEM } \\
\text { fields? }\end{array}$ & 4.15 & 0.99 & 4.20 & 0.84 & -0.12 & 0.91 \\
\hline & $\begin{array}{l}\text { by building } \\
\text { confidence in } \\
\text { STEM fields? }\end{array}$ & 4.15 & 1.04 & 4.17 & 0.41 & -0.06 & 0.95 \\
\hline & $\begin{array}{l}\text { by developing } \\
\text { new abilities in } \\
\text { STEM fields? }\end{array}$ & 4.21 & 0.98 & 3.40 & 1.52 & 1.13 & 0.31 \\
\hline & $\begin{array}{l}\text { by building better } \\
\text { relationships with } \\
\text { other students? }\end{array}$ & 3.90 & 1.07 & 3.67 & 0.82 & 0.57 & 0.58 \\
\hline & $\begin{array}{l}\text { by building a } \\
\text { better relationship } \\
\text { with the teachers? }\end{array}$ & 4.37 & 0.68 & 3.50 & 1.23 & 1.66 & 0.15 \\
\hline & $\begin{array}{l}\text { by building a } \\
\text { better relationship } \\
\text { with the Fellows? }\end{array}$ & 4.65 & 0.67 & 4.80 & 0.45 & -0.60 & 0.56 \\
\hline & $\begin{array}{l}\text { by building a } \\
\text { better relationship } \\
\text { with the graduate } \\
\text { Fellow? }\end{array}$ & 4.25 & 0.85 & 4.33 & 1.15 & -0.12 & 0.92 \\
\hline & $\begin{array}{l}\text { by building a } \\
\text { better relationship } \\
\text { with North } \\
\text { Carolina State } \\
\text { University? }\end{array}$ & 3.95 & 1.28 & 3.40 & 1.14 & 0.94 & 0.38 \\
\hline & $\begin{array}{l}\text { by building a } \\
\text { better relationship } \\
\text { with Shaw } \\
\text { University? }\end{array}$ & 3.37 & 1.61 & 3.33 & 1.53 & 0.04 & 0.97 \\
\hline
\end{tabular}

Table 5 is illustrative of the statistical inference collected in the second survey. This table reveals the statistically significant differences between the teacher and Fellow subgroups for one question. We performed two-sample t-test on the average Likert data for each question. When using a two-sided t-test at the 0.05 level, the majority of the questions showed that there were no significant differences among the two sub-groups. The only significant difference was found in the first question where the subgroups were asked "Does participation in an OST Club positively affect the students or teacher by building self-esteem?" All other questions were similarly analyzed and similar results were found (data not shown). Thus, we conclude that averaging the data for teachers and Fellows is sufficient for our analysis. 